\title{
STEP BY STEP CONVERSION TO ORGANIC AGRICULTURE
}

\author{
Alina Stancu ${ }^{1}$, Nicolae Suvorov ${ }^{2}$
}

\begin{abstract}
The controversial issue of genetically modified organisms and environmental pollution, which often leads to global warming, brings us face to face with the need to change the way agriculture leaves its mark on the ecological balance. If common efforts were focused on designing a multidisciplinary agricultural system that produces quantitatively and nutritionally sufficient food while protecting biodiversity and non-renewable resources, the problems that the agricultural sector generates would be greatly reduced. Paper provides introductory information linked to conversion from conventional to organic system of agriculture from the aspect of sustainable development. Familiarity with new eco-friendly practices is essential for exploiting the opportunities for the agricultural sector. In this context, the paper analyses the general consequences observed by some of globally recognized institutions involved in agriculture.
\end{abstract}

Key words: modern agriculture, sustainability, conventional agriculture, development, competitiveness.

JEL ${ }^{3}:$ I10, L66, Q18

\section{Introduction}

Agriculture is important sector of the resource-consuming economy that directly impacts global food security. Being the main source of food, agriculture uses many resources whose irresponsible utilization could cause negative environmental externalities for all ecosystems. Despite the huge short-term losses in terms of production (e.g. decline in yields that are felt in farmers' budget or the procedural difficulties linked to converting to organic agriculture) undeveloped countries usually do not consider such a big change in the agricultural sector as a priority. It is well known that organic farming is currently not so well legally regulated, while the certain changes occur all the time. Mostly weak training of farmers, as

1 Alina Madalina Stancu, Ph.D. Student, Bucharest University of Economic Studies, Piata Romana no. 6, 010374 Bucharest, Romania, Phone: +40 735361 478, E-mail: stancualina13@stud.ase.ro

2 Nicolae Suvorov, Ph.D. Student (corresponding author), Bucharest University of Economic Studies, Piata Romana no. 6, 010374 Bucharest, Romania, Phone: +40 740474 653, E-mail: suvorov.nicolae@gmail.com

3 Article info: Review Article, Received: 24 $4^{\text {th }}$ April 2021, Accepted: $1^{\text {st }}$ June 2021. 
another part of the problem, initiate that they are usually not familiar with organic farming techniques. Some of them, even if they are well prepared and want to be actively involved in sustainable development activities, do not have the necessary resources caused by insufficient funding of this sector, or lack of interest to approach to adequate external funds, specifically as the administrative procedures are too complicated for them. However, the global awakening regarding genetically modified organisms, the loss of biodiversity and non-renewable resources and global warming are leading to the need for an interdisciplinary approach on how to slow down or even stop consequences of current agriculture. So let's assume that the best alternative to solve the problem or reduce the risks related to previously mentioned issues is to achieve a step-by-step transformation oriented to sustainable future based on conversion of conventional to organic farming.

\section{Literature Review}

What is organic farming and how is it defined by scientific studies in the field? The most common definitions group together techniques, practices and working conditions used to fit into the organic concept and philosophy (e.g. Goldman, Hylton, 1972; Klonsky, Tourte, 1998; FAO, 1999; Bourn, Prescott, 2002). However, some definitions focus on the term "green" or "eco-friendly" (e.g., Goldman, Hylton, 1972), others on natural agricultural production systems and on the term "biological" and "ecological" (e.g. Klonsky, Tourte, 1998), while other emphasize the natural processes that do not involve the use of chemical fertilizers or other protective substances (FAO, 1999, Jeločnik et al., 2015). However, organic farming brings many benefits with intrinsic characteristics such as quality and safety (Vindigni et al., 2002). Moreover, this concept gives consumers the confidence to buy environmentally produced food precisely out of hope for a better life (Giannakas, 2002), being considered credence goods that regardless of label, content or studies proving quality, are purchased by consumers with their eyes closed (Andersen, Philipsen, 1998). A credence good is one that determines the purchase decision based on consumer perception, not necessarily on actual value.

However, organic food plays important role, both for human health, as it contains fewer chemicals, and for the environment, as it brings many benefits to overall nature (Davis, 1994). Besides, its real issues are high costs, lower yields, larger labor involvement, request for trained labor, etc. (El Hage Scialabba, Hattman, 2002).

In line to human health concerns to pollution of essential nature elements, organic food products become more and more popular among consumers, leading to increase in their demand (Marcu et al., 2020). Globally, in current economies, organic agri- 
food markets start to express much more proactivity through the increased volume of production and offer, revenues, and demand (Ladaru, 2018). Consumer behavior is strongly affected by the prices of organic food products, which are higher than conventional food. While purchasing them, the buying decision becomes easier as long as there is a positive correlation between the hope for a better and healthier life for the whole population (Garcia, Teixeira, 2017). Informing consumers correctly about the all benefits derived from organic products consumption, both from the aspect of human health or environmental aspect is absolutely necessary, as on that way it will be improved their awareness, helping them to make the correct decision and buy "chemically-free" food (Templer et al., 2018).

Certain studies are shown that in early years of conversion to organic farming, there come to huge losses in yields, as the soil needs some period for recovery (Halberg, Kristensen, 1997). For example, in case of potatoes losses reach $75 \%$ in first two years of conversion, while the average for other crops is from 20 to $50 \%$ yields' reduction (Connolly, 2002). On the other hand, losses incurred in organic farming will be covered by higher products' prices (Misra et al., 1991).

\section{Research Method}

Growing consumers' interest in cleaner and healthier food is increasingly raising the possibility of converting to organic farming. The main objective of the paper is to qualitatively analyze several comparative studies between conventional and organic farming, with a focus on eco-friendly practices, creating the information framework for the farmers that tend to invest in this sector of agriculture.

Analysis based on desktop research was the primary used research method. Besides, it was also used the methods of comparative analysis and deduction. Paper development involved consultation with the number of scientific and professional articles and studies thematically turned to observed field. Used material and documentation was searched through recognized scientific and institutional databases, in order to answer the main research questions: What is organic agriculture? What is better, organic farming or conventional farming? Is it more expensive? Can organic farming ensure global food security? What does conversion to organic farming entail and what are the economic, social and environmental impacts?

\section{Results and Discussion}

In the last decade, population tends to turn its attention to possibilities to reduce the risks related to pollution, environmental degradation, food processing, or some other issue. Both, the scientific audience and policy makers have concerns about making 
agriculture as sustainable activity useful for the development of disadvantaged areas and emerging countries. These concerns are concentrating around agricultural practices, trying to ensure the food security and health of the global population (Gregory, 2000), animal welfare (Hughes, 1995; Harper, Makatouni, 2002) and to minimize the anthropogenic footprint on the environment (Grunert, Juhl, 1995). For a better understanding of the need to convert into the organic farming, it is necessary to analyze the benefits it brings, as well as the possibility of sustainable development in the agricultural sector (Figure 1. and Figure 2.).

Figure 1. Environmental benefits of conversion to ecological agriculture

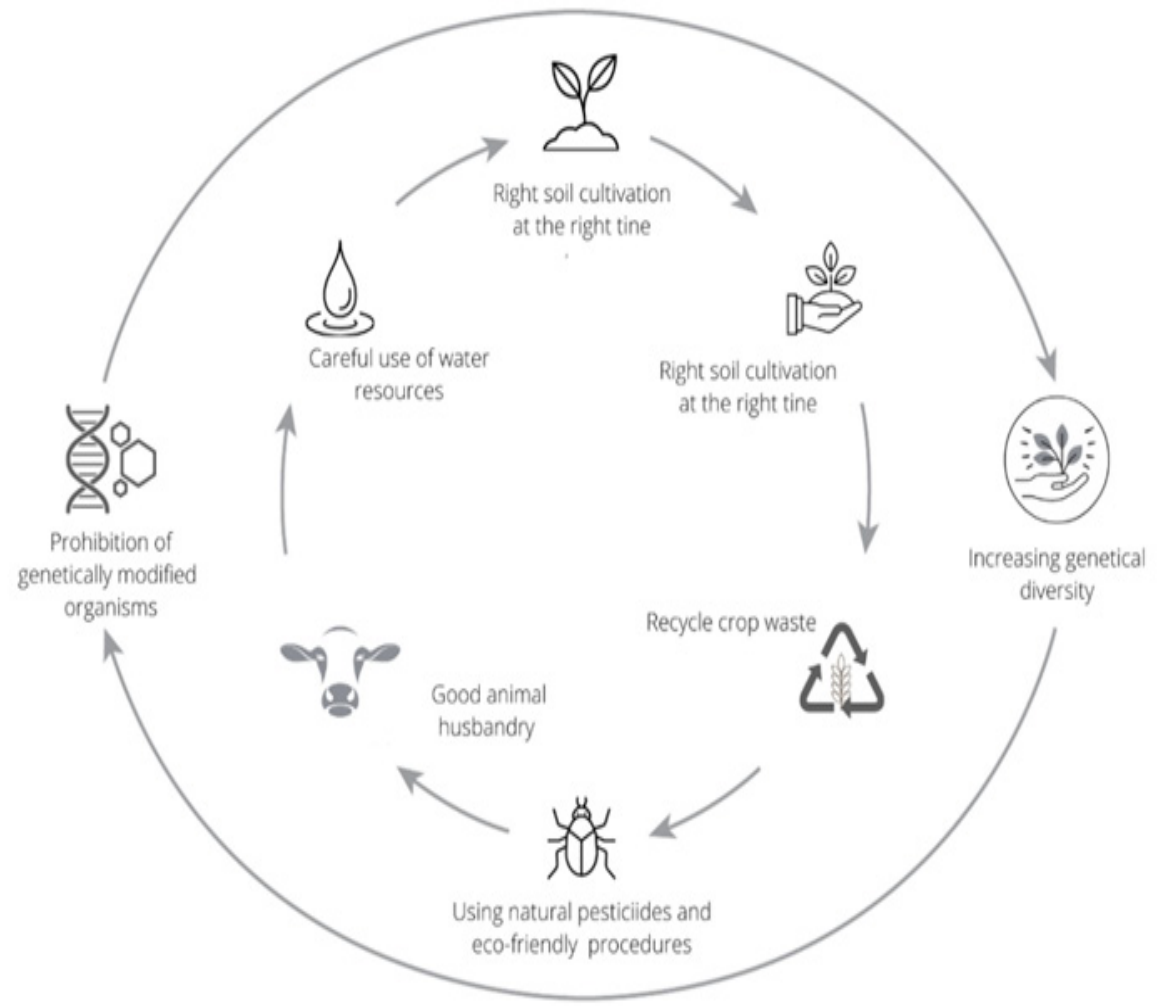

Source: Authors expression based on Garcia, Teixeira, 2017.

The first step in the process of converting to organic farming is to bring and implement the know-how on certain farm (Reganold, Wachter, 2016). Farmers that are interested in sustainable development, as a good start could be turned to understanding and studying management systems of natural process, available legislative framework, or financial possibilities, etc. Organic farming requires advanced practical knowledge and skills, while farmers can learn and adopt techniques, or receive information from 
other farmers who are already involved in organic farming. On the other hand, each farmer has to consider how he can contribute to sustainable development, e.g., some of them can grow legumes, or organic crops, while other can compost or recycle plant waste (Giannakas, 2002).

Figure 2. Importance and benefits of organic farming

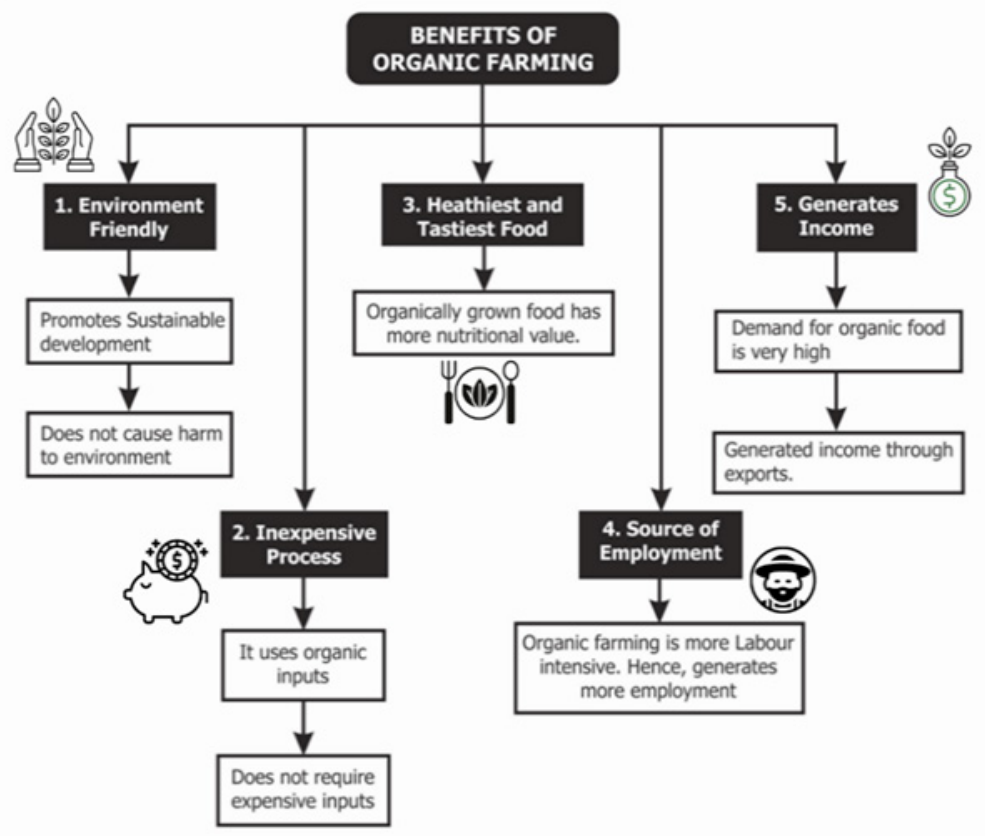

Source: Authors expression based on Meemken, Qaim, 2018.

Fully understanding the benefits that organic farming brings both to consumers and environment is necessary for organization of good farm management. Knowing that, farmers will be able to initiate step by step implementation of eco-friendly techniques, as well as to reduce the use of agro-chemicals in plant production, or antibiotics and drug treatments in animal husbandry (Hill, Lynchehaun, 2002). Mentioned steps for starting the conversion to organic farming are quite simple, and do not require large investments or advanced knowledge. It has relatively low risks but huge short-term impacts.

Additional analysis of organic versus conventional farming could be seen in next table (Table 1.). 
Table 1. Analysis of the benefits of conversion to organic farming

\begin{tabular}{|c|c|c|}
\hline Advantages & Disadvantages & Interesting facts \\
\hline $\begin{array}{l}\text { Organic vegetable crops are } \\
\text { superior in terms of nutrient } \\
\text { compounds and minerals } \\
\text { compared to those grown in } \\
\text { conventional farming systems }\end{array}$ & $\begin{array}{l}\text { Organic farming generates lower } \\
\text { yields and volume of production } \\
\text { level than conventional or } \\
\text { traditional farming }\end{array}$ & $\begin{array}{l}\text { In the last decade, organic } \\
\text { farming tends to become more } \\
\text { and more popular due to change } \\
\text { in consumers' behavior that is } \\
\text { turned towards cleaner food and } \\
\text { environmental protection. }\end{array}$ \\
\hline $\begin{array}{l}\text { Eco-friendly practices such as } \\
\text { intercropping, crop rotation, } \\
\text { organic fertilizers encourage the } \\
\text { development and conservation of } \\
\text { biodiversity, improve soil quality } \\
\text { and create more stable systems. }\end{array}$ & $\begin{array}{l}\text { Organic farming is time } \\
\text { consuming, requiring from } \\
\text { farmers more active and intensive } \\
\text { involvement in plant observation, } \\
\text { weed control and crop cultivation. }\end{array}$ & $\begin{array}{l}\text { Vertical farming using } \\
\text { hydroponic layers instead of soil } \\
\text { is to efficient way to grow organic } \\
\text { food in protected areas. It has } \\
\text { been expected to be more used in } \\
\text { recent years. }\end{array}$ \\
\hline $\begin{array}{l}\text { Organic farming largely } \\
\text { contributes risk reduction in } \\
\text { ground water pollution due to } \\
\text { well-structured management of } \\
\text { organic systems and ability of } \\
\text { plants to retain more nutrients. }\end{array}$ & $\begin{array}{l}\text { Organic farming requires } \\
\text { advanced knowledge, while } \\
\text { farmers usually do not find } \\
\text { complete solutions to all } \\
\text { problems they face. They need a } \\
\text { better understanding of the natural } \\
\text { balance to correct any issues. }\end{array}$ & $\begin{array}{l}\text { From the 90s when organic } \\
\text { farming growth was one } \\
\text { billion USD, it reached to } 30 \\
\text { billion USD in } 2011 \text {, while it } \\
\text { has continued growth by } 10 \% \\
\text { annually. Currently value is over } \\
100 \text { billion USD. }\end{array}$ \\
\hline $\begin{array}{l}\text { Organic agriculture reduces } \\
\text { the risks linked to intensive } \\
\text { use of non-renewable energy } \\
\text { sources and global warming } \\
\text { by decreasing the level of used } \\
\text { agrochemicals caused by ability } \\
\text { to fix carbon in soil. }\end{array}$ & $\begin{array}{l}\text { Veggies are not protected from } \\
\text { diseases and pests, while the use } \\
\text { of natural pesticides and eco- } \\
\text { friendly fertilizers can lead to } \\
\text { certain human illness, e.g. green } \\
\text { manure can contain pathogenic } \\
\text { bacteria that contaminate the } \\
\text { food. }\end{array}$ & $\begin{array}{l}\text { Organic food is not as clean as } \\
\text { expected. The USDA allows over } \\
40 \text { non-organic ingredients to be } \\
\text { present in organic food packages, } \\
\text { what usually means only } 98 \% \text { of } \\
\text { organic product. }\end{array}$ \\
\hline $\begin{array}{l}\text { Organically grown food has the } \\
\text { ability to stay fresh longer due to } \\
\text { its natural nutrition and superior } \\
\text { cellular metabolism, i.e. they are } \\
\text { less susceptible to spoilage. }\end{array}$ & $\begin{array}{l}\text { Organic feed is more expensive } \\
\text { for consumers due to necessity } \\
\text { of more material, financial } \\
\text { resources of farmers for whom } \\
\text { organic farming is not necessarily } \\
\text { profitable. }\end{array}$ & $\begin{array}{l}\text { Organic farms subject domestic } \\
\text { animals to the same "torture" } \\
\text { apart from administering drug } \\
\text { treatments. }\end{array}$ \\
\hline $\begin{array}{l}\text { Thanks to the natural treatments } \\
\text { that organic crops receive, there } \\
\text { is increase in resistance to the } \\
\text { drought. Use of green pesticides } \\
\text { increases the plants' defensive } \\
\text { capacity }\end{array}$ & $\begin{array}{l}\text { When converting to organic } \\
\text { farming, the soil does not adapt } \\
\text { so quickly, i.e. it needs the time to } \\
\text { recover from the loss of chemical } \\
\text { fertilizers, what results in few } \\
\text { years' lower yields. }\end{array}$ & $\begin{array}{l}\text { Farms practicing organic systems } \\
\text { are prohibited from the use of } \\
\text { GMO at any stage of production } \\
\text { or processing. The use of } \\
\text { unnatural additives, colorings and } \\
\text { preservatives in organic feed is } \\
\text { also prohibited. }\end{array}$ \\
\hline
\end{tabular}

Source: Bruinsma, 2003.

There are the examples of recommended techniques that could be used for the transfer from conventional to organic agriculture: 


\section{a) Mulching}

This technique is simple and involves covering the soil with a protective layer to increase moisture and fertility, thus contributing to soil health. Mulching can also reduce weed growth and improve the appearance of the harvest area. Mulching can be done with an organic layer of compost, manure, grass clippings, bark chips, or an inorganic layer of stones, plastic or bricks (Huang et al., 2020).

\section{b) Intercropping}

It is a practice that requires more knowledge in the field of plant growing and the natural cycles but is nevertheless often found in organic farming. It usually involves growing of two leguminous plants and alternating them usually with cereal crops. The main aim is to maximize the benefits of soil diversification by diversifying production while reducing competition between plants for available water, soil resources and light (Martin Guay et al., 2018).

\section{c) Compositing}

Applying compost as a fertilizer is a technique that also requires knowledge and experience, but small investment. In order to enrich soil fertility with nutrients farmers are applying considerable layer of compost. It represents a mixture of biomass, plant residues and manure. The most suitable plant residues for compost are legumes as contain almost all essential macronutrients (Onwosi et al., 2017).

\section{d) Green manuring}

Like composting, this technique is designed to enrich the soil with nutrients and increase its fertility. The main difference is that this layer is alive and mainly made up of legumes that are entirely used for biomass production. The practice requires experience and knowledge about the specificities of used crops, as well as process of their fixation of macro-elements in the soil, or what inputs they mainly need (Islam et al., 2019).

\section{e) Organic pest management}

Bio-control is very important to protect plant crops and animals from diseases and pests. Initially protective agents can be applied but the correct approach is to calculate the ratio between the used and unwanted pests so that there is a required balance. Eco-friendly alternatives to traditionally used pesticides very harmful to environment and humans, include the use of physical barriers (stones, shell powder), small insects or animals. Habitat modification is another practice in order to attract pollinators, or natural enemies that will be trapped in pheromone traps (Headrick, 2021). 


\section{f) Appropriate seeds materials}

The quality of the final product is directly influenced by the used raw material, while the quality of plant crops depends of used seeds. Seed or planting material is very important in crop production. Their origin must be known, while they must be genetically, chemically and bacteriologically clean. Considering the organic farming, the best method is to choose the local seed and planting material as they are resilient to local environmental conditions (Coelho et al., 2018).

\section{g) Growing farm-own animal feed}

Analysis of the food traceability from farm to fork shows that each stage of the agrifood chain is of major importance in generating the chemical, physical and biological risks. One of the main risks of contamination with chemical residues is usually identified within the phase of production. Feeding animals with contaminated feed is real problem that unfortunately has serious repercussions on the whole food chain. So, considering this organic farming recommends growing farms' own animal feed (Bleken et al., 2005).

\section{Conclusions}

As characteristic of decentralization, agriculture in Romania is often formed by small subsistence or semi-subsistence farms that, in order to ensure a sustainable development, need reorganization. Moreover, a multidisciplinary approach that considers overal sector of agriculture has to implement know-how from developed countries, while not only to ensure food security but also to protect the environment.

The conversion to organic farming can last for years, even decades and farmers involved in this change must be continuously supported in order to be able to generate enough production to go beyond semi-subsistence and contribute to feeding the population with more sustainable and nutritious food.

Another aspect of interest in entire agricultural sector is education. Farmers need to be adequately educated, or being more aware of the all impacts derived from the use of pesticides, drug treatments and other environmentally harmful substances, as well as to responsible use of non-renewable resources. Besides, overall population needs to change its consumption behavior. Sustainable development and environmental protection require synergistic actions by authorities, institutions, private sector, consumers and all actors involved in the agricultural sector. It is a long road, full of threats and obstacles both legislative and financial, but agricultural sector can flourish in a sustainable way if the adequate recommendations are implemented, while global or national vision on environmental protection is built on awareness. 


\section{References}

1. Andersen, E., Philipsen, K. (1998). The Evolution of Credence Goods in Customer Markets: Exchanging 'Pigs in Pokes'. Department of Business Studies, Aalborg University, Denmark.

2. Bleken, M., Steinshamn, H., Thuen, E., Koesling, M. (2005). Closing the plantanimal loop: A prerequisite for organic farming. In: $15^{\text {th }}$ IFOAM Organic World Congress, Nordic Association of Agricultural Scientists, Alnarp, Sweden, 1(1):147-152.

3. Bourn, D., Prescott, J. (2002). A comparison of the nutritional value, sensory qualities and food safety of organically and conventionally produced foods. Critical Reviews in Food Science and Nutrition, 42(1):1-34.

4. Bruinsma, J. (2003). World Agriculture: Towards 2015/2030: An FAOPerspective. Earthscan Publications Ltd, London, UK.

5. Coelho, J., Filipe, R., Robalo, M., Stateva, R. (2018). Recovering value from organic waste materials: Supercritical fluid extraction of oil from industrial grape seeds. The Journal of Supercritical Fluids, 141:68-77.

6. Connolly, L. (2002). Costs and Margins in Organic Production in Comparison with Conventional Production. In: Signposts to Rural Change, Proceedings Rural Development Conference, Rural Economy Research Centre, Athenry, Ireland, pp. 93-100.

7. Davis, J. (1994). Consumer response to corporate environmental advertising. Journal of Consumer Marketing, 11(2):25-37.

8. El Hage Scialabba, N., Hattman, C. (Eds.), (2002). Organic Agriculture, Environment and Food Security. Environment and Natural Resources Series no. 4, Food and Agricultural Organization, Rome, Italy, available at: www.fao.org/3/ Y4137E/y4137e00.htm\#TopOfPage, retrieved at $4^{\text {th }}$ April 2021.

9. FAO (1999). Organic Agriculture. Report from the $15^{\text {th }}$ session of the Committee on agriculture annual meeting, Food and Agricultural Organization of the UN (FAO), Rome Italy, available at: www.fao.org/unfao/bodies/COAG/COAG15/ X0075E.htm, retrieved at $5^{\text {th }}$ April 2021.

10. Garcia, J., Teixeira, P. (2017). Organic versus conventional food: A comparison regarding food safety. Food Reviews International, 33(4):424-446.

11. Giannakas, K. (2002). Information asymmetries and consumption decisions in organic food product markets. Canadian Journal of Agricultural Economics, 50(2002):35-50. 
12. Goldman, M., Hylton, W. (1972). The Basic Book of Organically Grown Foods. Rodale Press Book Division, Emmaus, USA.

13. Gregory, N. (2000). Consumer concerns about food. Outlook on Agriculture, 29(4):251-257.

14. Grunert, S., Juhl, H. (1995). Values, environmental attitudes and buying of organic foods. Journal of Economic Psychology, 16(1):63-72.

15. Halberg, N., Kristensen, I. (1997). Expected crop yield loss when converting to organic dairy farming in Denmark. Biological Agriculture and Horticulture, 14:25-41.

16. Harper, G., Makatouni, A. (2002). Consumer perception of organic food production and farm animal welfare. British Food Journal, 104(3-5):287-299.

17. Headrick, D. (2021). The Future of Organic Insect Pest Management: Be a Better Entomologist or Pay for Someone Who Is. Insects, 12(2):1-19.

18. Hill, H., Lynchehaun, F. (2002). Organic milk: Attitudes and consumption patterns, British Food Journal, 104(7):526-542.

19. Huang, Y., Liu, Q., Jia, W., Yan, C., Wang, J. (2020). Agricultural plastic mulching as a source of microplastics in the terrestrial environment. Environmental Pollution, 260(114096):1-6.

20. Hughes, D. (1995). Animal welfare: The consumer and the food industry. British Food Journal, 97(10):3-7.

21. Islam, M., Urmi, T., Rana, M., Alam, M., Haque, M. (2019). Green manuring effects on crop morpho-physiological characters, rice yield and soil properties. Physiology and Molecular Biology of Plants, 25(1):303-312.

22. Jeločnik, M., Ion, R., Jovanović, M., Popescu, C. (2015). Has organic farming potential for development? Comparative Study in Romania and Serbia. Procedia Economics and Finance, 22:268-276.

23. Klonsky, K., Tourte, L. (1998). Organic agricultural production in the United States: Debates and directions. American Journal of Agricultural Economics, 80(5):1119-1124.

24. Ladaru, R. (2018). Approaches on Trends, Constraints, and Transformations of Romanian Organic Agri-food Market. In: Sima, V. (Edt.) Organizational Culture and Behavioral Shifts in the Green Economy, IGI Global Press, Hershey, USA, pp. 167-180. 
25. Marcu, N., Ladaru, R., Diaconeasa, M. (2020). Challenges and opportunities in the Romanian organic food market considering youth preferences. In: Platania, M., Jeločnik, M., Gostin, I. (Eds.) Course for trainers: Organic farming, ecomarket and their capitalization through the entrepreneurial initiative, University of Alexandru Ioan Cuza, Iasi, Romania, pp. 33-63.

26. Martin Guay, M., Paquette, A., Dupras, J., Rivest, D. (2018). The new green revolution: Sustainable intensification of agriculture by intercropping. Science of the Total Environment, 615:767-772.

27. Meemken, E., Qaim, M. (2018). Organic agriculture, food security, and the environment. Annual Review of Resource Economics, 10(1):39-63.

28. Misra, S., Huang, C. L., Ott, S. L. (1991). Georgia consumers' preference for organically grown fresh produce. Journal of Agribusiness. 9:53-65.

29. Onwosi, C., Igbokwe, V., Odimba, J., Eke, I., Nwankwoala, M., Iroh, I., Ezeogu, L. (2017). Composting technology in waste stabilization: On the methods, challenges and future prospects. Journal of environmental management, 190:140-157.

30. Reganold, J., Wachter, J. (2016). Organic agriculture in the twenty-first century. Nature plants, 2(2):1-8.

31. Templer, N., Hauser, M., Owamani, A., Kamusingize, D., Ogwali, H., Mulumba, L., Onwonga, R., Adugna, B., Probst, L. (2018). Does certified organic agriculture increase agroecosystem health? Evidence from four farming systems in Uganda. International Journal of Agricultural Sustainability, 16(2):150-166.

32. Vindigni, G., Janssen, M. A., Jager, W. (2002). Organic food consumption: A multi-theoretical framework of consumer decision making. British Food Journal, 104(8):624-642. 